Respiratory Sciences, University of Leicester, Leicester, UK

2 Civil and Environmental Engineering, Virginia Tech, USA

3 Department of Mechanical Engineering, University of Hong Kong, Hong Kong, China

4 Edinburgh Napier University and NHS Lanarkshire, Edinburgh, UK

Correspondence to: J W Tang julian.tang@uhl-tr.nhs.uk

Cite this as: BMJ 2021;373:n913 http://dx.doi.org/10.1136/bmj.n913

Published: 14 April 2021

\section{Covid-19 has redefined airborne transmission}

\author{
Improving indoor ventilation and air quality will help us all to stay safe \\ Julian W Tang, ${ }^{1}$ Linsey C Marr, ${ }^{2}$ Yuguo Li, ${ }^{3}$ Stephanie J Dancer ${ }^{4}$
}

Over a year into the covid-19 pandemic, we are still debating the role and importance of aerosol transmission for SARS-CoV-2, which receives only a cursory mention in some infection control guidelines. $^{12}$

The confusion has emanated from traditional terminology introduced during the last century. This created poorly defined divisions between "droplet," "airborne," and "droplet nuclei” transmission, leading to misunderstandings over the physical behaviour of these particles. ${ }^{3}$ Essentially, if you can inhale particles-regardless of their size or name-you are breathing in aerosols. Although this can happen at long range, it is more likely when close to someone, as the aerosols between two people are much more concentrated at short range, rather like being close to someone who is smoking. ${ }^{4}$

People infected with SARS-CoV-2 produce many small respiratory particles laden with virus as they exhale. Some of these will be inhaled almost immediately by those within a typical conversational "short range" distance $(<1 \mathrm{~m})$, while the remainder disperse over longer distances to be inhaled by others further away ( $>2 \mathrm{~m})$. Traditionalists will refer to the larger short range particles as droplets and the smaller long range particles as droplet nuclei, but they are all aerosols because they can be inhaled directly from the air. ${ }^{5}$

Why does it matter? For current infection control purposes, most of the time it doesn't. Wearing masks, keeping your distance, and reducing indoor occupancy all impede the usual routes of transmission, whether through direct contact with surfaces or droplets, or from inhaling aerosols. One crucial difference, however, is the need for added emphasis on ventilation because the tiniest suspended particles can remain airborne for hours, and these constitute an important route of transmission.

If we accept that someone in an indoor environment can inhale enough virus to cause infection when more than $2 \mathrm{~m}$ away from the original source-even after the original source has left-then air replacement or air cleaning mechanisms become much more important. ${ }^{6} 7$ This means opening windows or installing or upgrading heating, ventilation, and air conditioning systems, as outlined in a recent WHO document. ${ }^{8}$ People are much more likely to become infected in a room with windows that can't be opened or lacking any ventilation system.

A second crucial implication of airborne spread is that the quality of the mask matters for effective protection against inhaled aerosols. Masks usually impede large droplets from landing on covered areas of the face, and most are at least partially effective against inhalation of aerosols. However, both high filtration efficiency and a good fit are needed to enhance protection against aerosols because tiny airborne particles can find their way around any gaps between mask and face. ${ }^{910}$

If the virus is transmitted only through larger particles (droplets) that fall to the ground within a metre or so after exhalation, then mask fit would be less of a concern. As it is, healthcare workers wearing surgical masks have become infected without being involved in aerosol generating procedures..$^{11-13}$ As airborne spread of SARS-CoV-2 is fully recognised, our understanding of activities that generate aerosols will require further definition. Aerosol scientists have shown that even talking and breathing are aerosol generating procedures. ${ }^{14-16}$

It is now clear that SARS-CoV-2 transmits mostly between people at close range through inhalation. This does not mean that transmission through contact with surfaces or that the longer range airborne route does not occur, but these routes of transmission are less important during brief everyday interactions over the usual $1 \mathrm{~m}$ conversational distance. In close range situations, people are much more likely to be exposed to the virus by inhaling it than by having it fly through the air in large droplets to land on their eyes, nostrils, or lips. ${ }^{17}$ The transmission of SARS-CoV-2 after touching surfaces is now considered to be relatively minimal. ${ }^{18-20}$

Improved indoor air quality through better ventilation will bring other benefits, including reduced sick leave for other respiratory viruses and even environmentally related complaints such as allergies and sick building syndrome..$^{21} 22$ Less absenteeism-with its adverse effect on productivity-could save companies significant costs, ${ }^{23}$ which would offset the expense of upgrading their ventilation systems. Newer systems, including air cleaning and filtration technologies, are becoming ever more efficient. ${ }^{24}$

Covid-19 may well become seasonal, and we will have to live with it as we do with influenza. ${ }^{25}$ So governments and health leaders should heed the science and focus their efforts on airborne transmission. Safer indoor environments are required, not only to protect unvaccinated people and those for whom vaccines fail, but also to deter vaccine resistant variants or novel airborne threats that may appear at any time. Improving indoor ventilation and air quality, particularly in healthcare, work, and educational environments, will help all of us to stay safe, now and in the future. 
aspects of covid-19 (including transmission) at meetings sponsored by Thea Pharmaceuticals, Thornton \& Ross, Landsec, and is conducting a study funded by Sanofi Pasteur on the effect of timing of seasonal influenza vaccination in healthcare workers on their vaccine induced immunity. LCM does consultancy for CrossFit, MITRE Corporation, and Smiths Detection.

Provenance and peer review: Commissioned; not externally peer reviewed.

1 World Health Organization. Transmission of SARS-CoV-2: implications for infection prevention precautions. 9 Jul 2020. https://www.who.int/news-room/commentaries/detail/transmission-ofsars-cov-2-implications-for-infection-prevention-precautions

2 Centers for Disease Control and Prevention. How COVID-19 Spreads. Updated 28 Oct 2020 https://www.cdc.gov/coronavirus/2019-ncov/prevent-getting-sick/how-covid-spreads.html

3 Tellier R, Li Y, Cowling BJ, Tang JW. Recognition of aerosol transmission of infectious agents: a commentary. BMC Infect Dis 2019;19:101. doi: 10.1186/s12879-019-3707-y pmid: 30704406

4 Tang JW, Bahnfleth WP, Bluyssen PM, etal. Dismantling myths on the airborne transmission of severe acute respiratory syndrome coronavirus-2 (SARS-CoV-2). J Hosp Infect 2021;110:89-96. doi: 10.1016/j.jhin.2020.12.022 pmid: 33453351

5 Morawska L, Milton DK. It is time to address airborne transmission of coronavirus disease 2019 (COVID-19). Clin Infect Dis 2020;71:2311-3. doi: 10.1093/cid/ciaa939. pmid: 32628269

6 Morawska L, Cao J. Airborne transmission of SARS-CoV-2: the world should face the reality. Environ Int 2020;139:105730. doi: 10.1016/j.envint.2020.105730 pmid: 32294574

7 Morawska L, Tang JW, Bahnfleth W, etal. How can airborne transmission of COVID-19 indoors be minimised? Environ Int2020;142:105832. doi: 10.1016/j.envint.2020.105832 pmid: 32521345

8 World Health Organization. Roadmap to improve and ensure good indoor ventilation in the context of COVID-19. 2021. https://www.who.int/publications/i/item/9789240021280

9 Fennelly KP. Particle sizes of infectious aerosols: implications for infection control. Lancet Respir Med 2020;8:914-24. doi: 10.1016/S2213-2600(20)30323-4 pmid: 32717211

10 Drewnick F, Pikmann J, Fachinger F, Moormann L, Sprang F, Borrmann S. Aerosol filtration efficiency of household materials for homemade face masks: influence of material properties, particle size, particle electrical charge, face velocity, and leaks. Aerosol Sci Technol2021;55:63-79. doi: 10.1080/02786826.2020.1817846.

11 Nguyen LH, Drew DA, Graham MS, etalCoronavirus Pandemic Epidemiology Consortium. Risk of COVID-19 among front-line health-care workers and the general community: a prospective cohort study. Lancet Public Health 2020;5:e475-83. doi: 10.1016/S2468-2667(20)30164-X pmid: 32745512

12 Klompas M, Baker MA, Rhee C, etal. A SARS-CoV-2 cluster in an acute care hospital. Ann Intern Med 2021:M20-7567. doi: 10.7326/M20-7567. pmid: 33556277

13 Goldberg L, Levinsky Y, Marcus N, etal. SARS-CoV-2 infection among health care workers despite the use of surgical masks and physical distancing-the role of airborne transmission. Open Forum Infect Dis 2021;8:b036. doi: 10.1093/ofid/ofab036. pmid: 33732749

14 Asadi S, Wexler AS, Cappa CD, Barreda S, Bouvier NM, Ristenpart WD. Aerosol emission and superemission during human speech increase with voice loudness. Sci Rep 2019;9:2348. doi: 10.1038/s41598-019-38808-z pmid: 30787335

15 Scheuch G. Breathing is enough: for the spread of influenza virus and SARS-CoV-2 by breathing only. J Aerosol Med Pulm Drug Deliv 2020;33:230-4. doi: 10.1089/jamp.2020.1616 pmid: 32552296

16 Stadnytskyi V, Bax CE, Bax A, Anfinrud P. The airborne lifetime of small speech droplets and their potential importance in SARS-CoV-2 transmission. Proc Natl Acad Sci US A2020;117:11875-7. doi: 10.1073/pnas.2006874117 pmid: 32404416

17 Chen W, Zhang N, Wei JJ, Yen HL, Li Y. Short-range airborne route dominates exposure of respiratory infection during close contact. Build Environ 2020;176:106859. doi: 10.1016/j.buildenv.2020.106859

18 Goldman E. Exaggerated risk of transmission of COVID-19 by fomites. Lancet Infect Dis 2020;20:892-3. doi: 10.1016/S1473-3099(20)30561-2 pmid: 32628907

19 Haug N, Geyrhofer L, Londei A, etal. Ranking the effectiveness of worldwide COVID-19 government interventions. Nat Hum Behav 2020;4:1303-12. doi: 10.1038/s41562-020-01009-0 pmid: 33199859

20 Scientific Advisory Group for Emergencies (SAGE). What is the evidence for the effectiveness of hand hygiene in preventing the transmission of respiratory viruses? https://assets.publishing.service.gov.uk/government/uploads/system/uploads/attachment_data/file/897598/S0574_NERVTAG-EMG_paper_-_hand_hygiene_010720_Redacted.pdf

21 Laumbach RJ, Kipen HM. Bioaerosols and sick building syndrome: particles, inflammation, and allergy. Curr Opin Allergy Clin Immunol 2005;5:135-9. doi: 10.1097/01.all.0000162305.05105.d0 pmid: 15764903

22 Sundell J, Levin H, Nazaroff WW, etal. Ventilation rates and health: multidisciplinary review of the scientific literature. Indoor Air 2011;21:191-204. doi: 10.1111/j.1600-0668.2010.00703.x pmid: 21204989

23 Bramley TJ, Lerner D, Sames M. Productivity losses related to the common cold. J Occup Environ Med 2002;44:822-9. doi: 10.1097/00043764-200209000-00004 pmid: 12227674

24 Song Y, Wu S, Yan YY. Control strategies for indoor environment quality and energy efficiency-a review. Int J Low Carbon Technol 2015;10:305-12. doi: 10.1093/ijlct/ctt051 .

25 Murray CIL, Piot P. The potential future of the covid-19 pandemic: will SARS-CoV-2 become a recurrent seasonal infection?JAMA 2021;325:1249-50.

doi: 10.1001/jama.2021.2828 pmid: 33656519
This article is made freely available for use in accordance with BMJ's website terms and conditions for the duration of the covid-19 pandemic or until otherwise determined by BMJ. You may use, download and print the article for any lawful, non-commercial purpose (including text and data mining) provided that all copyright notices and trade marks are retained. 